\title{
Da'wah Culture at Jamaah Tabligh in Medan, North Sumatra
}

\author{
Dr. Sahrul, M.Ag \\ Lecturer at State Islamic University of North Sumatra, UINSU, Medan, Indonesia
}

\begin{abstract}
The purpose of this study is to find out the culture of Jamaah Tabligh in the implementation of sermon (da'wah) in Medan City. The culture of da'wah includes five things. (1). Khurujya which means migration, going from mosque to mosque or from one region to another in groups led by one person called Jaulah Amir (leader). (2) Jaulah which means visiting people's homes to be invited to pray together and listen to Islamic studies at the mosque. (3) Khususi which means visiting the Islamic scholars, kiai, Islamic teachers, preachers, local government, community leaders, youth and the rich who are considered quite influential in religion, social, educational and economic. (4). Ta'limwa at-taklum is a culture of learning and teaching in mosques. (5). Bayan means Islamic lectures in mosques in the form of halaqah (circle), the duration of lecture kulibas (fifteen minutes lecture) kudupul (twenty minutes lecture), asking and answering.

The type of this research is qualitative that uses ethnographic approach, the method of data collection; in-depth interviews, participative observation and documentation study. The techniques of analyzing the data used taxonomy, comparison, contextualization, and conceptualization, techniques of validity of the data examination, quantity technique and the quality of the involvement, precision observation, triangulation and the adequacy of reference.
\end{abstract}

Keywords: da'wah culture; JamaahTabligh; zhikir: sunnah

\section{INTRODUCTION}

One of active Islamic organizations in the field of preaching in Medan City, North Sumatra is Jamaah Tabligh. It is said so because the organization of Jamaah Tablighis synonymous with the jamah who deliver preaching in groups and often migrate from a mosque to other mosque or from one region to another. Bringing adequate meals (Amwal), staying in the mosque for a certain time. Their activities are learning about Qur'an, praying together, zikir (remembering to Allah) together after pray and listening to amir' (leader) sermon. Their characteristics are wearing white turbans, white shirts, some had long beards and pants that do not cover the ankles which is often called hanging pants. From their religious attributes it seems that they are quite happy to show their identity as different from other mosque congregations in general.

Abu Muhammad bin Ahmad Abduh states that Jamaah Tablighis a collection of gatherers who invite people to the path of goodness and prevent the man from the cursed path (Ahmad Abduh, 2008: 5). The foundation of the establishment (Al Imran: 110) is practicing consistently the Sunnah (tradition) of the Prophet Muhammad PBUH either in terms of words, deeds and proof.

The presence of Jamaah Tabligh in various mosques seemingly adds an increasing $d a$ 'wah activity although it is undeniable that there are pros and cons attitudes in the society. The pro attitude means agreeing to $d a$ 'wah activities carried out by Jamaah Tabligh. The reason is they prosper mosques, they are discipline in prayer, quite Islamic dressed, friendly, have solidarity and always keep the environment of the mosques clean. Meanwhile the contra attitude is quite disagree with the $d a$ 'wahpattern they carry out, the reason is quite simple that is they are too symbolic, fanatics to their group, they often leave the family at home as if it they did not give sufficient living and less concerned about the future of education and the family income.

The pros and cons attitudes aimed at JamaahTabligh do not lessen their spirit to develop da'wah but on the contrary they are used as an input, correction and motivation to strengthen their activities and including trying to realize the da'wah culture. The da'wah culture covers five terms (1) Khuruj (2) Jaulah (3)Khususi (4) Taklimwa at-taklum and (5). Bayani.

The $d a$ 'wah culture means ideology or ideas, customs, symbols, norms, art, language and knowledge (Sahrul, 2011: 83). Kuntowijoyo says that culture is the idea, the symbols and values that affect people's behavior (Kuntowijoyo, 2001: xi). Ideology or ideas are noumena and phenomena. Noumenameans normative or abstract which is difficult to observe, meanwhile, is phenomenon is social symptoms that can be observed empirically. The five $d a$ 'wah cultures of JamaahTablighbelong to social phenomenon domain. The more details can be seen in the following description. 


\section{METHODOLOGY}

This research is a qualitative study that tries to explain the results of research in the form of written words that are the result of in-depth interviews, observation and documentation. The characteristics are idealistic, rational, critical, humanist and empirical (Bungin, 2012: 4-5). Sugiono says that qualitative research is based on empirical data which is used to examine the natural object, the researcher is as a key instrument, with a purposive sampling and snowbaal, data collection method; interview, observation and documentation. The data analysis is inductive and the research results obtained are more emphasized on the meaning rather than a generalization (Sugiono, 2014: 15).

The approach used is ethnography which is meant to understand the characteristics of social and cultural life of a society from the inside and outside (Patji, 2005: 15). The data analysis techniques used are taxonomy, comparison, contextualization, and conceptualization based on the comparison of characteristics, sequence and causality relationship. Taxonomy is to find the relationship between the parts of culture that can describe the culture as a whole, the comparison means to compare between culture with another culture that has to do with the culture studied, contextual is a study of culture which is current event or developing within a community. While the conceptualization means making a figure of the research result in general and specific.

The techniques of checking data validity used quantity and quality of involvement technique, rigor of observation, using triangulation theory; methods and data, discussion with colleagues and the adequacy of reference. Triangulation theory is combining several theories used as the basis for the conduct of research. Triangulation method is a combining multiple methods in a research. Triangulation data is retrieval data from various sources. The keywords of triangulation basically should not be bias or intervention of the data. Discussion with colleagues means discussions with people who understand more about the culture being studied. While the adequacy of reference means the availability of books, magazines, and bulletins related to the object of the research.

\section{DISCUSSION}

The $d a$ 'wah cultures of Jamaah Tablighin Medan City, North Sumatra covers first, khuruj(migration) means move from one mosque to another mosque within a certain period, for example one week, two weeks, three weeks and four weeks, the longest time is 90 days or three months. During khuruj they bring enough meal (Amwal), keeping health and in groups consist of seven to 10 people, led by a man called amir (leader) (Shahab, 2007: 101). The basic of doing khurujis (Al Imran: 110). The word ukhrijatlinnasi means issued to human which means da'wah will not be perfect if it preformed permanently, but it is much more effective to move from mosque to mosque or from one region to another. The advantages are there is a different atmosphere found, a new spirit, a new congregation and avoiding from being bored in preaching. The disadvantages are the da'wah carried out is not optimal, it is more routines and the da'wah management is less planned. Another meaning of the word ukhrijatlinnasi is human since Adam AS until now (Shihab, 2011: 221).

The culture of khuruj da'wah which developed by Jamaah Tabligh is adopted from the da'wah culture of Prophet Muhammad PBUH in Mecca period that invited family and closest friends, to convert to Islam. Its basis is Surah Asy-Syu'ara: 214) "And warn (Muhammad) your closest kindred." The strategy is in secret, semi-secret and overt. This da'wah culture is synonymous with fardiyahda'wah culture which is now re-applied by JamaahTabligh.

During the khuruj activities, there are nine ethics that they must have, (1). Wake up at midnight to pray Tahajjud. (2). Eat less (3). Stay in the mosque; do the remembrance of Allah and prayer. (4). Avoid talking useless thing. (5). They are not allowed to talk about politics and power. (6). They are not allowed to wear other people's things without asking permission of the owner. (7). They should not be burdensome and ask khuruj fee from people around the mosque. (8). Wear Islamic dress (close the genitals). (9). Maintain the cleanliness of the mosque.

Second, culture of jaulah is the members of the group visit people's homes to convey the da'wah messages along with ask them to pray together in the mosque. The group of jauhlah is divided into two, they are (1) the group in the mosque to wait for the gatherers who will come. (1). Groups that are inside the mosque to wait for pilgrims coming. (2). The group outside the mosque whose duty is visiting people's homes. They consist of dalil, mutakallim, makmur and amirjauhlah.. They are well-dressed, wearing turban, white robe and holding a rosary. Dalil here does not mean argument. Dalil here means a guide. Dalil generally consists of local people who are recruited to become members of TablighiJamaat and given the task to record the scholars' homes, teachers, preachers, community leaders who are considered have influences from the point of religion, social, economic and political, and even they record individual or group who do not want to pray to the mosque.

Mutakallim are spokesmen who are given the task to convey the messages of da'wah to the society. Besides makmur, the members of jaulah are not allowed to talk. Makmur have duties to do the remembrance to Allah (zikir) in the heart and not allowed to talk. Amir jauhlah means a group leader who has the task as a leader, giving direction, deciding whether jaulah should be continued or not and conducting social control over 
members of jaulah if there is there is a wrong deed. Warnings are not in the form of words but with a signal by saying subhanallah.

The group which is in the mosque consists of zakirin, muqarrar, mustamik and istiqbal. Zakirinis a person whose task is to perform the remembrance of Allah and pray so that the members who carry out jaulah outside the mosque managed to invite people to pray to the mosque. Muqarrar means a person whose task is to repeat the conversation. Mustami' is a person whose task is to listen to the conversation of amirjaulah. Meanwhile istiqbal is a person who is given the task to welcome the gatherers who come to the mosque, greetings, to read a prayer into the mosque, to welcome and to perform tahyat al-masjid prayer, to sit and to do the remembrance to Allah.

The two groups that perform jaulah, must have five characteristics, they are:

1. Fikir (Think), the implementation of jaulah based on rational thinking so that the people who are invited receive the da'wah and pray together in the mosque.

2. Zikir (Remembrance of Allah), to recall and to get closer to Allah SWT so that the da'wah delivered to the gatherers around the mosque is received in a positive response and has intimate relationship.

3. Ikhlas (Being sincere) means being thankful in implementing in jaulah and only want to get the pleasure of Allah.

4. Syukur(Being thankful) means being grateful to be included in jaulah to ask people to the good way and prevent the people from the evil way because not everyone has the opportunity to participate in jaulah and this should be grateful.

5. Sabar (Being patient) means having a spirit to go ahead, being calm, consistent and resistant to the test. For example, if the local people who are asked to the good way do not want to do so then they have to be patient, do not be angry, even they are prayed so that they receive guidance from Allah.

Besides having five characteristics as mentioned above, jaulah members must also have ethical da'wah namely:

1. Always pray to Allah SWT so that the implementation of jaulah will have no any obstacle. The purpose is the mosque is having more and more gatherers in every five daily prayers.

2. Walking on the right side and lowering the eyes to the front, meaning that the foresight cannot to the front continuously that may reflect pride.

3. The position of Amir (leader) walk is behind and those who walk at the front is dalil and mutakallim. Like in the military, the soldiers are at the front row while the commander is at the back.

4. Avoiding stand at the front door of the visited house because standing at the front door as seen as aurat of jaulah because they can see the whole households.

5. Dalil knocks on the door three times if the house is closed, if the door is open then dalil will say salam. At the time dalil knocks the door or says salam, mutakallim perform the remembrance of Allah and prays silently. If there is no response from the house owner then jauulahleftteh house with khusnuzzan (good prejudice).

6. If the house owner shows a positive response, then asked to be seated, dalil are not allowed to speak except mutakallim to explain the purpose of their visiting in asking the house owner to the mosque to pray.

7. Jauhlah is not allowed to perform if there comesazan (praying call) by muezzin to prayer at the mosque. The reason is due to the praying call must respected and all activities and conversations must be stopped.

8. Jaulahis performed before Maghrib (sunset) prayer or adapted to the local conditions. If the local people commonly stay at home at night then jaulah is held at night before Maghrib prayers or before Isya prayers.

The third is da'wah culture of khususi which means visiting the houses of the community leaders, Islamic teachers, scholars, preachers, the rich, local government, karkun and duafa. The culture of khususida'wah is also called relationship. The proportion is the saying of Allah SWT in An-Nisa '/ 4: 1, ie:

"O mankind. Fear your Lord, who created you from one soul and created from it its mate and dispersed from both of them may men and women. And fear Allah and keep your ties".

The culture of khususida'wah and jaulah actually has the differences and similarities. The difference is khususi is performed without any time limitation and there is no division of groups as in jaulah culture has. The participants of khususi are two or three people and a maximum of five people. From an ethical of da'wah, khususi has some ethics to the public, namely:

1. Shalathajat (need prayer) two rakaat (cycles) and praying for the success of jamaah in carrying out the task, having protection, mercy and hidayah (guidance) from Allah as well as their families left at home.

2. Dress neat, clean and cover up.

3. The implementation of khususi does not need to be determined by amir or leader.

4. The position of dalil is in front and the khususi members are behind. The purpose is to determine the position of the amir and khususi.

5. The members of khususi cannot stand on the doorstep of the invited people's house, because standing in front of the door is considered less polite because it will easily see households including genitals. 
6. Dalil has a task to knock on the door if it is closed and when the door is open he or she must say salam. If there is a response from the home owner, they are invited to pray in the mosque if there is no answer and then they leave the home with good prejudice.

7. KhususiJamaatare not allowed enter the house without any permission from the owner of the house.

8. When the home owners give any respond, questions, feedback, and critique, the participants of khususi must listen with concentration and are not allowed to protest. This is the manners of visiting are really cared.

9. The participants of khususi are not allowed to debate, argue with the home owners although there are offensive statements.

10. If the home owner gives criticism, the insulting words, being hateful, rude and angry, khususi participants must prioritize his or her patience and sincere and pray for guidance from Allah SWT.

Meanwhile the ethics of $d a^{\prime}$ wah to the scholars are:

1. The participants of khususi are not allowed to convey any da'wah to the scholars because the scholars are regarded as the persons who have much knowledge, the heir of the prophet, having noble morality and their knowledge level is not the same as the khususijamaah.

2. The presence of khususi participants to the scholars' homes must be based on respect, humility and fraternal.

3. To the scholars, they are allowed to discuss, have a dialogue and ask about religion but not allowed to argue and decline their opinions.

4. If the scholars ask about the development of JamaahTabligh, then tell them based on the the facts, there is no an element of bias and lying.

The ethics of da'wah to the local government are

1. Supporting the local authorities in enforcing amar makruf (enjoining the right doing) and nahimungkar (forbidding the wrong doing) which are parts of the leader's responsibilities.

2. Conveying the development of Jamaah Tabligh in the local government area and asking any moral support to the expansion of da'wah in the future.

3. Local authorities are invited to pray together in the mosque, which is much valuable than individual prayer.

4. Paying a visit to the local government's homes must be based on politeness, respect and helping each other.

The ethics of da'wah to the rich are

1. Dress neat, clean and cover up.

2. KhususiJamaah are not allowed to ask about the source of one's wealth, because, it is feared to offend.

3. The rich are asked to pay zakat (alms), donation, and charity to the poor and needy and the importance of da'wah.

4. The rich are asked to jihad (striving in the cause of Allah) with their wealth and lives. As the jihad of alRashidun Caliphs; Abu Bakr al-Siddiq, Umar bin Khattab, UthmanibnAffan and Ali bin AbiTalib who sincerely provided their wealth for the sake of the Prophet Muhammad PBUH.

5. The rich are asked to be active in prayer together in the mosque as part of the obligations of Muslims, especially the neighboring mosque.

6. Allowed to submit the stories of the rich in the history of Islam if it is allowed by the home owner.

7. If the stories told and the rich do not give any positive response then khususijamaah are not allowed to get angry, be offended and hate but to pray hopefully they get guidance from Allah SWT.

The ethics of $d a^{\prime}$ wah to the needy are

1. After the prayers, then disperse on the land to find the gift of Allah in His blessing.

2. To the poor are told about the importance of faith, Islam and righteousness in daily lives. This world is a heaven for the believers and hell for the infidels.

3. Conveying the stories of poor people in history such as the story of Bilal bin Rabah Abu Hurairah R.A. and some others that they were precious in Allah's sight.

4. The poor and the needy in the Allah's sight are not despised people but honorable enough because of the distribution of zakayharta (wealth alms), zakat fitrah and distribution of $2 / 3$ sacrificial meat which is allocated to the poor and the needy that is why they cannot be lazy to work but invariably endeavor. Allah's grace is covers earth and sky.

5. Praying for the poor and the needy to be given the physical and spiritual strength to perform prayers together in the mosque. They must not despair of the Allah's mercy, they cannot stand idly but keep on trying.The ethics of da'wah to the karkun.karkun is a fellow member of TablighiJamaat. Da'wah is given to karkun when their spirit began to decrease and do not focus because of far away from family members, feeling bored, and feeling lazy to perform prayer together. To this karkunjamaah, there are some ethics of da' wah: 
1. Appreciating their sacrifices for joining jaulah and khususi. If they are not respected it will cause hatred and animosity among the members of karkun.

2. Praying to be given physical and spiritual strength to perform prayers together in the mosque.

3. Do not ask why they do not take part in khuruj but it is better strengthened the relationship to him.

4. Honoring his family and not degrading the grade of karkun.

The fourth is the culture of taklimwa at-taklum, it means learning and teaching. The materials being learned are about the stories of the Prophet Muhammad PBUH, fadhilah (good quality) reading Al-Quran, the primacy of charity, the month of Ramadan, and the preferences of relationship. Teaching means amirjaulah describes taklim materials. The position of jamaah is circular (halaqah), amirjauhlah is in the middle of thejamaah. The culture of taklim is divided into three, they are

1. Taklim at home, it means learning again at home, adopting them and including practicing them to the wife and children.

2. Taklim in the mosque, it means adopting charity deeds learned in the mosque, every time in jamaah is at least 10 minutes, especially fadhilahsalat (prayer deeds) on time, tahajjud (midnight) prayer,Duha (after sunrise) prayer, fasting on Mondays and Thursdays.

3. Taklim with khuruj fi sabilillah, it means practicing what have learned among the khuruj fellow members.

The materials of taklumwa at-taklum are

1. Reading the book of fadhilah charity.

2. Correcting the recitation of the Qur'an in makhraj al-huruf, fasahah, and rhythm as well as tajwid (perfecting) knowledge.

3. Studying the characters of the Prophet Muhammad PBUH; siddiq, fatanah, amanahand tabligh (sermon)

4. Learning and practicing good behaviors and avoiding disgrace behaviors. The good behaviors are zuhud,iffah(avoiding of wrong doing), sincere, patient, forgiving, friendly, polite, honest, trustworthy, disciplined, and always giving charity to the poor and needy. The disgrace behaviors are liar, betrayal, arrogant, greedy, pitting, envy, dishonesty, corrupt and fun.

Besides having the materials, taklimwa at-taklum is not conducted arbitrarily but it must have ethics that divided into two physical and batiniyah (heart) ethics. The physical ethics are:

1. Doing ablution first so that being focus of remembrance of Allah, and sit down iftiras facing the direction to kiblat (ka'bah) and wear perfume.

2. Reading the Al-Quran or Hadiths of the Prophet Muhammad PBUH.

3. Reading blessings on the Prophet Muhammad PBUH.

4. If being told about heaven then say tasbih (Subhan Allah), tahlil (La ilahailla Allah) and Tahmid (alhamdulillah).

5. If being told about hell then saynanguzubillah (keep away) Ya Allah.

6. Jamaahare not allowed to leave the house before the event is over. If there is any jamaah who wants to urinate or against the ablution, he or she enough gives a signal by pointing his or her finger. If there is one who wants to leave the assembly just raises his or her hands up to the shoulder.

The ethics of Batiniyah are:

1. Always praise the greatness and omnipotence of Allah on earth.

2. Believing that Islam is the true religion and out of Islam is rejected by Allah.

3. Applying the teachings of Islam in private and family life.

4. Knowledge about religion is also conveyed to family, friends and neighbors and the Muslims in general.

The fifth is the culture of bayanda'wah. The meaning of bayan is identical with preaching which the materials are about tauhid (faith), ibadah (worship), akhlak (morality) danmuamalah (related to others). The person who performs bayan is called $d a{ }^{\prime} i$ or muballigh. The culture of bayan generally is held after Maghrib (sunset) and Fajr (sunrise) prayers together in the mosque in order to the jamaat understand the teachings of Islam and practice them in daily life either in personal or family life.

The culture of bayan is divided into three things:

1. Bayan hidayah. It is the messages of da'wah delivered by amirjaulah to the members of jamaat who will khuruj from mosque to mosque or to the selected area with adequate meals, taking care of health, being patient, sincere, they must not forget the responsibility of the family and always be optimistic in preaching.

2. Bayan Maghrib. It means the da'wah activities are carried out after Maghrib prayers together in the mosque. The materials are about faith, worship, morality, making prosper the mosque and charity.

3. Bayan wabsi. It is the messages of da'wah which are delivered to the jamaat who has returned from khurooj, mainly related to opportunity, successes, weaknesses and challenges they face. 
In the culture of bayan, it is also found some elements of da'wah in it, as follows:

1. $D a$ ' $i$ is the person who asks jamaah to Islamic way. In the science of communication it is called a communicator.

2. Mad'u or jamaah who listen to tausiah (sermons)

3. Materials which contains the Islamic message conveyed to jamaah

4. Media is a means to convey the message; printed and electronic media.

5. The feedback or response from the jamaah.

Besides findin $g$ out the elements of da'wah, there are two forms of bayan ethics which the da'I should have, they are:

a. Physical wthics; well-dressed, soft-spoken in preaching, not allowed to talk about politics, khilafiah, bid'ah, khurafat, takhayul, and the religious speech cannot be too long, just kulibas (fifteen minutes lecture) andkulpuh (twenty minutes lecture) .

b. Btiniyah Ethics which among them are; body free of major or small impurity, have ablution, shalathajad two cycles, and pray to Allah that the da'wah conveyed are accepted and practiced by jamaah.

\section{CONCLUSION}

JamaahTabligh with the attributes of religious they wear is quite popular and grounded in some communities in Medan City for actively carrying out $d a$ 'wah activities from mosque to mosque or from one region to another within the specified time of one week, two weeks up to three months. In another words their culture of $d a$ 'wah is different from the culture of da'wah in other Islamic organizations such as Muhammadiyah, Nahdlatul Ulama (NU), Al Jam'iyatulWashliyah, Al-Ittihadiyah and Tarbiyah Islamiyah. The cultures of da'wah include five terms. (1). Khuruj (migration). (2). Jauhlah (visiting the homes of residents. (3) Khususi which means visiting the house of the scholars, Kiai, teachers, da'i, muballigh, local government, community leaders, youth, and the rich. (4) $\mathrm{Ta}$ ' lumwa at-ta'lum which means learning and teaching in the mosques. (5). The culture of bayanida'wah (religious speech).

[1] Al-Quran al-Karim

\section{REFERENCES}

[2] Abduh, Abu Muhammad bin Ahmad. 2008. KupasTuntasJamaahTabligh, Jilid1. Bandung: KhairuUmmah.

[3] Bungin, Burhan, 2007. PenelitianKualitatif. Jakarta: Kencana.

[4] Liliweri, Alo, 2014. PengantarStudiKebudayaan. Bandung: Nusa Media.

[5] Kuntowijoyo. 2001. Muslim TanpaMesjid. Bandung: Mizan

[6] Maryaeni, 2005.MetodePenelitianKebudayaan. Jakarta: BumiAksara.

[7] Patji, Abdul Rahman. 2005. Agama danPandanganHidup. Jakarta: LIPI.

[8] Pirzada, Abdul Khaliq. Maulana Muhammad Ilyas: Di antaraPengikutdanPenentangnya, Yogyakarta: AsShaff.

[9] Sahrul, 2011.Sosiologi Islam. Medan: IAIN Press.

[10] Shahab, An-Nadhir M. Ishaq, 2007. Khuruj Fi Sabilillah. Bandung: PustakaRamadan.

[11] Shihab, M. Quraish, 2010, Tafsir Al-Misbah, Jilid 2. Jakarta: LenteraHati, 2010. 